\title{
LOCALIZATION OF GHRELIN IN THE EPITHELIAL CELLS OF THE DUODENUM IN THE RAT
}

\author{
S. Hamza ${ }^{1}$, I. Valkova ${ }^{1}$, P. Atanasova ${ }^{2}$, M. Gulubova ${ }^{3}$ \\ ${ }^{1}$ Department of Anatomy, Faculty of Medicine, Trakia University, Stara Zagora, Bulgaria \\ ${ }^{2}$ Department of Anatomy, Histology and Embryology, Faculty of Medicine, \\ Medical University, Plovdiv, Bulgaria \\ ${ }^{3}$ Department of General and Clinical Pathology, Faculty of Medicine, Trakia University, \\ Stara Zagora, Bulgaria
}

\begin{abstract}
Ghrelin is a hormone discovered relatively recently, the effect of which is associated with the normal activity of the digestive tract. It is the most abundant in the gastric mucosa, but also occurs in other parts of the digestive system, sexual organs and some glands. Many authors associate the action of ghrelin with appetite and weight gain or weight loss.

The purpose of this study was by immunohistochemical methods to localize grelin-pozitive cells in the duodenal mucosa and comparatively to determine their amount. We use Ghrelin (H-40) antibody (Santa Cruz-USA), and for the visualization of the results - detection system EnVisionTM FLEX Mini Kit, High $\mathrm{Ph}$ (DAKO - k8024 HRP). Histomorphometric study performed by Michael Vinther Image Analyzer, Version 1.33 (Mee Soft, Germany).
\end{abstract}

Key words: ghrelin, antibody, gastric epithelium, epithelial cells

\section{INTRODUCTION}

Ghrelin is a hormone discovered relatively recently, the effect of which is associated with the normal activity of the digestive tract. It is the most abundant in the gastric mucosa, but also occurs in other parts of the digestive system, sexual organs and some glands. Some investigators describe Des-acyl ghrelin as a food intake hormone (1) and many authors associate the action of ghrelin with appetite, obesity in humans (2) and weight gain or weight loss (3). Two major forms of ghrelin are described (4).

According Sato et al. (5) ghrelin is a stomach hormone that acts as an endogenous ligand of orphan G-protein-coupled receptor. It is a 28 amino acid peptide existing in two major forms: n-octanoyl-modified ghrelin, which possesses an n-octanoyl modification on serine-3 and des-acyl ghrelin. The same authors described the grelin as a peptide consisting of 28 amino acids, and is unusual among peptide hormones of which Ser3 is noctanoylated. This modification, the first known case in mammals, is essential for ghrelin's activity.
An enzyme that catalyses the acylmodification of ghrelin is discovered by Yang et al. (6). Zhang et al. (7) described a 23-amino acid peptide that they named obestatin. It has the ability to inhibit food intake in mice by intraperitoneal or intracerebroventricular injection. In addition, the authors reported that peripheral injection of obestatin inhibited jejunal contraction, suppression of gastric emptying and decreased body-weight gain (8). According Date and al. (9) ghrelin is present in X/A-like cells, which are about $20 \%$ of the endocrine cell population in adult oxyntic glands. Ghrelin-immunoreactive cells are also found in the duodenum, jejunum, ileum and colon.

Many author associates ghrelin with the stimulation of the growth factor secretion in human and animals $(10,11)$.

\section{AIM AND METHODS}

The aim of this investigation is to localize the ghrelin in the epithelial cells in the duodenum of the rat.

The material fixed in $10 \%$ aqueous formaldehyde for 48 hours, then embedded in 
paraffin in accordance with the requirements of $56^{\circ} \mathrm{C}$ standard paraffin inclusion. Using ultramicrotome (Ultracut, Germany) did slice thickness $4 \mu \mathrm{m}$.

For realization of this aim we used an immunohistochemical methods Ghrelin (H40) SC- 50297 Company Santa Cruz, USA. Results visualized detection system Daco - En Vision FLEX - Mini Kit.

We applied immunohistochemical methods Ghrelin (H- 40) SC- 50297 Company Santa Cruz, USA. Results visualized detection system Daco - En Vision FLEX - Mini Kit.

\section{RESULTS AND DISCUSSION}

Single ghrelin positive cells are observed in the duodenal mucosae. Frequently they are localized in the duodenal glands and in the cover epithelium (Figure 1). Our results are in accord of other publications (4, 12, 13). According Cojima and Kangawa (14) ghrelin immunoreactive cell density is lower in the duodenal mucosae in comparison with gastric mucosae but they are more in duodenum that in lower parts of the small intestine. In the intestine, ghrelin concentration gradually decreases from the duodenum to the colon.

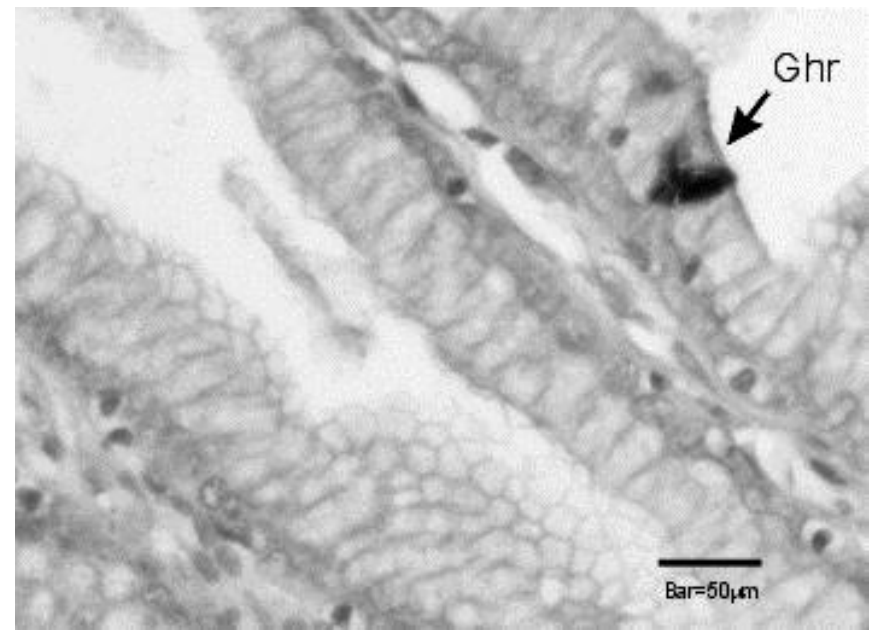

Figure 1. Ghrelin-positive cell in duodenal mucosae

Two type - closed- and opened-type of ghrelinproducing cells exist in the rat (15) and two major forms of ghrelin peptide - ghrelin and des-acyl ghrelin are described in rat gastrointestinal tissues (4). The main molecular forms of intestinal ghrelin are n-octanoil and des-acyl ghrelin like to the stomach ghrelin (14).

\section{CONCLUSION}

Numerous ghrelin-positive cells are described in X/A-like cells in adult stomach. Ghrelinimmunoreactive cells are found in all parts of gastrointestinal tract but their quantity is in varying degrees in the different digestive organs.

\section{REFERENCES}

1. Toshinai, K., H. Yamaguchi, Y.Sun, R. Smith, A. Yamanaka, T. Sakurai, Y. Date, M. Mondal, T. Shimbara, T. Kawagoe, N. Murakami, M. Miyazato, K. Kangawa, M. Nakazato. Des-acyl ghrelin induces food intake by a mechanism independent of the growth hormone secretagogue receptor. Endocrinology, 2006, 147, 2306-2314.
2. Ukkola, O., E. Ravussin, P. Jacobson, E. Snyder, M. Chagnon, L. Sjostrom, C. Bouchard, Mutations in the preproghrelin/ghrelin gene associated with obesity in humans. J. Clin. Endocrinol. Metab., 2001, 86, 3996-3999.

3. Hansen, T., R. Dall, H. Hosoda, M. Kojima, K. Kangawa, J. Christiansen, J. Jorgensen. Weight loss increases circulating levels of ghrelin in human obesity. Clin Endocrinol, 2002, 56, 203-206

4. Hosoda, H., Kojima, M., Matsuo, H., and Kangawa, K. (2000) Ghrelin and Des-acyl ghrelin: two major forms of rat ghrelin peptide in gastrointestinal tissue. Biochem. Biophys. Res. Commun., 2000, 279, 909913.

5. Sato, T., Y. Nakamura, Y. Shiimura, H. Ohgusu, K. Kangawa, M. Kojima1, Structure, regulation and function of ghrelin. J Biochem, 2012, 151(2): 119-128.

6. Yang, J., M. Brown, G. Liang, N. Grishin, J. Goldstein. Identification of the acyltransferase that octanoylates ghrelin, an appetite-stimulating peptide hormone. Cell, 2008, 132, 387-396. 
7. Zhang, J.V., Ren, P.G., Avsian-Kretchmer, O., Luo, C.W., Rauch, R., Klein, C., and Hsueh, A.J. Obestatin, a peptide encoded by the ghrelin gene, opposes ghrelin's effects on food intake. Science, 2005, 310, 996999.

8. Gourcerol, G., M. Million, D. Adelson, Y. Wang, L. Wang, J. Rivier, D. St-Pierre, Y. Tache. Lack of interaction between peripheral injection of Cck and obestatin in the regulation of gastric satiety signaling in rodents. Peptides, 2006, 27, 2811-2819.

9. Date, Y., M. Kojima, H.Hosoda, A. Sawaguchi, M. Mondal, T. Suganuma, S. Matsukura, K. Kangawa, M. Nakazato, Ghrelin, a novel growth hormone-releasing acylated peptide, is synthesized in a distinct endocrine cell type in the gastrointestinal tracts of rats and humans. Endocrinology, 2000, 141, 4255-4261.

10.Hataya, Y., T. Akamizu, K. Takaya, N. Kanamoto, H. Ariyasu, M. Saijo, K. Moriyama, A. Shimatsu, M. Kojima, K. Kangawa, K. Nakao, K. A low dose of ghrelin stimulates growth hormone (Gh) release synergistically with Gh-releasing hormone in humans. J. Clin. Endocrinol. Metab., 2001, 86, 4552.
11.Takaya, K., H. Ariyasu, N. Kanamoto, H. Iwakura, A. Yoshimoto, M. Harada, K. Mori, Y. Komatsu, T. Usui, A. Shimatsu, Y. Ogawa, K. Hosoda, T. Akamizu, M. Kojima, K. Kangawa, K. Nakao. Ghrelin strongly stimulates growth hormone release in humans. J. Clin. Endocrinol. Metab., 2000, 85, 4908-4911.

12.Hamza, S., I. Valkova, D. Sivrev, N. Dimitrov. Grelin-pozitive cells in rats. Scientific Journal of National University of Bioresources and Ecology of Ukraina. Kiev, 2013, 183-187.

13.Hamza, S., I. Vulkuva, M. Gulubova, P. Atanassowa, D. Sivrev. Expression of Ghrelinpositive Cells in the Stomach of the Rat. Acta morphologica et anthropologica, 2015, 21:51-54.

14.Cojima, M., K. Kangawa. Ghrelin: Structure and Function. Physiol Rev, 2005, 85: 495-522.

15.Sakata, I., K. Nakamura, M. Yamazaki, M. Matsubara, Y. Hayashi, K. Kangav, T. Sakai. Ghreling-producing cells exist as two types of cells, closed- and opened-type cells, in the rat gastrointestinal tract. Peptides, 2002, 23: 531-536. 